\title{
An Analysis of the Historical Records for the Native Mammalian Fauna of Prince Edward Island
}

\author{
Douglas G. SoBeY \\ Research Associate, Institute of Island Studies, University of Prince Edward Island, Charlottetown, Prince Edward Island \\ C1A 4P3 Canada \\ Summer address: P.O. Box 4004, Bedeque, Prince Edward Island C0B 1C0 Canada \\ Formerly: School of Applied Biological Sciences, University of Ulster, Jordanstown, Northern Ireland, BT37 0QB United \\ Kingdom
}

Sobey, D. G. 2007. An analysis of the historical records for the native mammalian fauna of Prince Edward Island. Canadian Field-Naturalist 121(4): 384-396.

A search was carried out for historical records, both published and unpublished, that make reference to the native mammalian fauna of Prince Edward Island. Based on documents dating from 1721 to 1890, a comprehensive list of the records for the native mammals of the island has been compiled. Among the new information found is evidence for the presence of the Grey Wolf (as well as the Woodland Caribou) at the time of the first French settlement in 1720, and for the absence of the Beaver and Moose. Historical information has been assembled on the abundance and food-chain relationships of each of the mammalian species, as well as on their interactions with the European population, including the attitudes of the new settlers towards each species. The records indicate that seven of the mammals were extirpated: the Grey Wolf, American Black Bear, American Marten, River Otter, Canada Lynx, Atlantic Walrus and Woodland Caribou. All of these extirpations were due to the activities of the European population, with the attitudes of the settlers contributing to four of them: an indifference to the survival of the otter and Marten, and a direct hostility to the bear and lynx (due to their predation on livestock), leading to the payment of bounties.

Key Words: historical records of mammals, mammalian fauna, Prince Edward Island, Grey Wolf, American Marten, Atlantic Walrus, Woodland Caribou, Moose, Beaver.

At the time of the first European settlement on Prince Edward Island in 1720, the island supported a varied mammalian fauna. In the course of the next 180 years, the native fauna was to become greatly reduced, with six terrestrial species (five of them predators) and one marine mammal being eliminated from the system. Despite an awareness of this general picture (e.g., Clark 1959), the many historical accounts relating to the island's native mammalian fauna have never been subjected to comprehensive analysis. It was hoped that a detailed examination of the records would not only reveal what species were present when European settlement began, but also yield information on the interactions between the native fauna and the European population, including the extent to which the fauna contributed to the food supply of the human population and to any fur-trade economy that developed, as well as an understanding of the factors that led to the extirpation of most of the fur-bearing predators. Initially, my aim was to examine only the records for the terrestrial fauna, though later the pinnipeds occurring in island waters (i.e., the seals and the walrus) were also included.

\section{The historical context}

Prince Edward Island (known as Île Saint-Jean to the French) was "discovered" by Jacques Cartier in 1534. However, historical accounts in any significant numbers only begin to occur from 1720 , the year of the arrival of some 250 colonists from France. (See Clark (1959) for an in-depth study of the island's historical geography.) Prior to the arrival of the French, aboriginal use by the Mi'kmaq appears to have been confined to the summer period, as part of their seasonal migration to the coastal areas of the Maritimes, though with the establishment of the first French settlement some of the Mi'kmaq began to spend the whole year. The French population grew slowly, so that by 1748 there were only 735 persons. However, numbers then rose sharply, reaching almost 5000 by 1758 , due to the arrival of Acadian refugees from the Bay of Fundy area on account of the political unrest and deportations occurring in Nova Scotia. After the fall of Louisbourg in 1758 almost all of the Acadian population was deported to France by the British military authorities, or fled to the mainland, leaving only a few hundred refugees. From the 1770s British settlement proceeded slowly, with by 1805 the population reaching only 6957 . However, it then began to grow exponentially, reaching 71000 by 1855 , when immigration from the British Isles began to end. Even so, natural growth continued, with numbers peaking at 109000 in 1891 (Clark 1959). This increase in the human population was associated with a decrease in the area forested, and by 1935 only $32 \%$ of the land area still had a forest cover (Glen 1997).

Prior to European settlement virtually all of the island's land area of some $5750 \mathrm{~km}^{2}$ had been covered by old-growth forest, with the predominant forest-type, 
TABLE 1. Twenty-one lists of the mammals of Prince Edward Island - made by different recorders between 1721 and 1890 . The lists are in chronological order, with the names of the recorders given below the table - these are fully referenced at the end of the paper. See the main text for the identification of the species. (E - extirpated - i.e., reported as either no longer occurring on the island, or the evidence is for the past occurrence only; A - reported as absent from the island.) *

\begin{tabular}{|c|c|c|c|c|c|c|c|c|c|c|c|c|c|c|c|c|c|c|c|c|c|c|}
\hline \multirow[b]{2}{*}{ MAMMAL } & \multicolumn{21}{|c|}{ THE Lists } & \multirow[b]{2}{*}{ TOTAL } \\
\hline & 1 & 2 & 3 & 4 & 5 & 6 & 7 & 8 & 9 & 10 & 11 & 12 & 13 & 14 & 15 & 16 & 17 & 18 & 19 & 20 & 21 & \\
\hline 'Shrew' & & & & & & & & & & & & & & & & & $\bullet$ & & & & - & 2 \\
\hline 'Bat' & & & & & & & & & & & $\bullet$ & & $\bullet$ & & & & $\bullet$ & & & & • & 4 \\
\hline 'Mole' & & & & & & & & & & & & A & & & & & - & & & & • & 2 \\
\hline 'Wolf' & - & & & & & & & & & & & & & & & & A & & & - & - & 3 \\
\hline 'Fox' & $\bullet$ & $\bullet$ & $\bullet$ & $\bullet$ & $\bullet$ & $\bullet$ & • & $\bullet$ & $\bullet$ & $\bullet$ & $\bullet$ & $\bullet$ & $\bullet$ & $\bullet$ & $\bullet$ & $\bullet$ & $\bullet$ & $\bullet$ & $\bullet$ & $\bullet$ & $\bullet$ & 21 \\
\hline 'Bear' & & • & • & & $\bullet$ & $\bullet$ & • & • & • & • & • & $\bullet$ & - & - & • & • & • & • & $\bullet$ & $\bullet$ & • & 19 \\
\hline 'Marten' & • & - & - & • & - & • & - & & - & • & • & • & - & - & & - & • & • & • & • & - & 19 \\
\hline 'Weasel' or 'ermine' & & & & & & & & & & & - & & - & & & - & • & • & & & • & 6 \\
\hline 'Mink' & & & • & & • & & • & & $\bullet$ & • & - & • & - & • & & - & - & & • & - & - & 14 \\
\hline 'Otter' & $\bullet$ & $\bullet$ & & - & • & $\bullet$ & - & & • & - & - & & - & - & & - & - & - & - & - & - & 17 \\
\hline 'Wild cat' or lynx & & - & $\bullet$ & & - & $\bullet$ & - & $\bullet$ & - & • & $\bullet$ & $\bullet$ & $\bullet$ & & - & $\bullet$ & • & $\bullet$ & $\bullet$ & - & $\mathrm{E}$ & 18 \\
\hline 'Seals' & & - & - & & • & • & • & & • & • & • & - & • & • & & & • & & - & - & $\bullet$ & 15 \\
\hline 'Sea cow' or walrus & & & & & - & & - & & - & - & - & & E & $\mathrm{E}$ & & & $\mathrm{E}$ & & $\mathrm{E}$ & $\mathrm{E}$ & $\mathrm{E}$ & 11 \\
\hline 'Caribou' & • & • & & & • & & & & & & & & & & $\mathrm{E}$ & $\mathrm{E}$ & $\mathrm{A}$ & $\mathrm{E}$ & & & & 6 \\
\hline 'Moose' & A & & & & & & & & & & & & & & $\mathrm{E}$ & $\mathrm{E}$ & $\mathrm{A}$ & A & $\mathrm{E}$ & $\mathrm{E}$ & $\mathrm{E}$ & 5 \\
\hline 'Deer' & & & & & & & & A & & & & & & & & & & A & & $\mathrm{E}$ & & 1 \\
\hline 'Squirrels' & & & & & & $\bullet$ & - & & $\bullet$ & $\bullet$ & & & & & & & & & $\bullet$ & $\bullet$ & & 6 \\
\hline Red squirrel & & & & & & & & & & & • & • & • & & & • & • & & & & • & 6 \\
\hline Flying squirrel & - & & & & & & & & & & - & • & • & & & - & • & & & & - & 7 \\
\hline Chipmunk & & & & & & & & & & & $\bullet$ & • & • & & & • & $\bullet$ & & & & $\bullet$ & 6 \\
\hline 'Beaver' & A & & & & & & & & & & & & & & & & A & A & & & $\mathrm{E}$ & 1 \\
\hline 'Muskrat' & & • & & • & • & & & • & - & - & • & - & • & & & - & $\bullet$ & $\bullet$ & - & • & $\bullet$ & 15 \\
\hline 'The plague mouse' & & - & - & • & & $\bullet$ & & - & & & • & & • & & & & • & & • & • & & 10 \\
\hline Other mice and voles & & - & & & & & - & & & • & & • & & & & & • & & & & - & 6 \\
\hline 'Hare' or 'rabbit' & & • & - & • & $\bullet$ & • & - & • & $\bullet$ & • & $\bullet$ & - & - & & • & $\bullet$ & $\bullet$ & • & $\bullet$ & • & - & 19 \\
\hline TOTAL & 6 & 11 & 8 & 6 & 11 & 9 & 11 & 6 & 11 & 12 & 16 & 12 & 16 & 7 & 6 & 14 & 19 & 9 & 13 & 15 & 21 & \\
\hline
\end{tabular}

The recorders: 1 - La Ronde 1721; 2 - Roma 1750; 3 - Franquet 1751; 4 - Pichon 1760; 5 - Holland 1765; 6 - Patterson 1770; 7 - Patterson 1774; 8 - Shuttleworth 1793; 9 - [Cambridge] c. 1796; 10 - Walsh 1803; 11 - Stewart 1806; 12 - Johnstone 1822; 13 - MacGregor 1828; 14 - Hill 1839; 15 - Lawson 1851; 16 - Bagster 1861; 17 - Sutherland 1861; 18 Rowan 1876; 19 - Anonymous 1876; 20 - [Lawson] 1877-1878; 21 - Bain 1890.

* List 19 is a composite list assembled from the responses of eighteen men to several questions on the mammals occurring on the island in their "young days", contained in a questionnaire sent out in 1876 to the "oldest inhabitants" by a Charlottetown historical committee; list 20 has been put together from anecdotes on the island's native fauna contained in a series of nineteen articles on pioneer life published in 1877 and 1878 in the Presbyterian and Evangelical Protestant Union.

particularly in the central part, consisting of hardwood forest in which American Beech (Fagus grandifolia) especially, but also Sugar Maple (Acer saccharinum) and Yellow Birch (Betula alleghaniensis) predominated (Sobey and Glen 2002, 2004; Sobey 2006). In the eastern and western parts, where there was a higher proportion of poorly drained soils, other forest-types occurred, especially a type of "swamp" woodland, containing Red Maple (Acer rubrum), Eastern Whitecedar (Thuja occidentalis), Black Ash (Fraxinus nigra) and American Elm (Ulmus americana), as well as a boreal forest-type in which Black Spruce (Picea mariana) predominated along with a minority element of Tamarack (Larix laricina). The upland hardwood forest in particular was subjected to large-scale clearance for agriculture, with any remnants (often in the form of farm woodlots), undergoing considerable change due to the continual harvesting of selected species for timber and firewood. As well, in all forest-types there were the damaging effects of the ubiquitous forestfires associated with forest clearance. The removal of this old-growth forest and the alteration of that which remained would have had considerable consequences for the island's mammalian fauna.

\section{Results}

From the beginning of European settlement in 1720 there is a regular flow of relevant documents from the French (1720-1758), British (1758-1873) and postConfederation periods (1873 to $c .1900$ ). These comprise both published books, such as immigrants' handbooks and travel accounts (most of which were 
available in the P.E.I. Collection of the Robertson Library of the University of Prince Edward Island), and unpublished documents, including government records and private journals, many of which were housed in the Provincial Archives and Public Records Office in Charlottetown (PEI PARO). Some 58 documents were found that make reference to one or more of the native mammals of the island - these are fully reported in Sobey $(2002,2006)$. Especially informative are those records where the writer constructed a list of the mammals of the island: twenty-one such lists have been assembled in Table 1. Four come from the French period (all based on observations made between 1720 and 1752) and seventeen from the British and post-Confederation periods. Many of these listmakers also made short comments on the abundance and/or ecology of some or all of the mammals, as well as on their relations with the human population.

The lists range from four recorders who mention only six species, to one listing twenty-one. All but four of the list-makers appear to have been resident on the island for at least a year, and most for many years. The exceptions are Franquet $(1751 \dagger)$, Pichon $(1760 \dagger)$, Walsh (1803†) and Rowan (1876 $\dagger$ ), who spent from seventeen days to a few months. However, given the elusive nature of most of the mammals, it is unlikely that even the resident recorders would have seen every animal they listed, and it is especially likely that animals that were known to have occurred in the past would have continued to have been listed for some time after their extirpation. Also, there is a likelihood that some of what they record may derive not from their own observations, or even from the anecdotal experience of other island residents, but from general written sources from elsewhere.

Table 1 indicates that, collectively, there is a bias in the selection of the animals recorded. The smaller mammals (the shrews, bats and rodents) were either ignored, or else were treated generically, except by a few of the late nineteenth century "scientific" recorders, such as Sutherland $(1861 \dagger)$ and Bain $(1890 \dagger)$, whereas a greater coverage was given to those mammals considered "useful" to the human population; i.e., as a source of food or products such as furs. Also, some of the animals received greater attention because of their predation on the settlers' livestock and poultry. The records for each mammal are presented separately below, with the nomenclature and order following that of Scott and Hebda (2004).

\section{Shrews}

The Atlantic Canada Conservation Data Centre (ACCDC 2008*) lists five species of shrew as currently occurring on Prince Edward Island: the Masked Shrew (Sorex cinereus), Water Shrew (Sorex palustris), Smoky Shrew (Sorex fumeus), Pigmy Shrew (Sorex hoyi), and Northern Short-tailed Shrew (Blarina brevicauda). However, the only historical records for the presence of shrews are those of Sutherland $(1861 \dagger)$ and Bain $(1890 \dagger)$, who recorded the presence of what they called the "shrew mouse" and "shrew mole", respectively (Table 1), both mentioning that it fed on insects.

\section{Bats}

ACCDC (2008*) lists four species of bat for Prince Edward Island: the Little Brown Bat (Myotis lucifugus), Northern Long-eared Bat (Myotis septentrionalis), Hoary Bat (Lasiurus cinereus), and Eastern Red Bat (Lasiurus borealis). For the Eastern Red Bat there is a sight record only. Not surprisingly, the four recorders who noted the presence of bats (Table 1) listed them as if only one species were present. All four recorders indicated that bats were common during the summer, and Bain $(1890 \dagger)$ said that they "[hid] away in some secure cranny in buildings or in a hollow tree".

\section{Grey Wolf}

The only certain record for the Grey Wolf (Canis lupus) is that of La Ronde (1721†), who said that there were wolves "of a prodigious size" on the island. That he also added that he was sending a wolf pelt back to France from the island, both supports his record and indicates they were vulnerable to the presence of the newly arrived Europeans, though it is not impossible that it was the Mi'kmaq who were responsible for the kill. Since there is no further mention of the presence of wolves in eighteenth century records, it is possible that the Grey Wolf was extirpated shortly after settlement began, or else moved across the ice to the mainland. It is thus surprising that there are a couple of late post-Confederation mentions of its presence ([Lawson] 1877-1878†; Bain 1890†), both of which report, on the basis of anecdotal and second-hand information of unknown date, wolves as transient visitors. What Bain $(1890 \dagger)$ says is that "wolves have been known to cross the Northumberland Strait on the ice and visit the Island". If this ever occurred, it was likely to have been long before the 1890s when the island was at the peak of European settlement and forest clearance, and when according to Lohr and Ballard (1996) the Grey Wolf was very scarce on the mainland.

\section{Red Fox}

The Red Fox (Vulpes vulpes) occurs in all twentyone lists (Table 1), with several recorders noting it as common (MacGregor 1828†; Sutherland 1861†; Anonymous $1876 \uparrow$; Bain $1890 \dagger$ ). Others noted the presence of different colour phases (e.g., Franquet $1751 \dagger$; [Cambridge] c. $1796 \dagger$; Stewart 1806 $†$ ): red, black, and silver-grey are the most frequently listed, though all noted that the red phase was by far the predominant. A fox fur of any colour seems to have had some value, though it was the blacks and silver-greys that were especially sought after. Stewart $(1806 \dagger)$ said that the number of foxes caught on the island was 
"very considerable", while the means of catching them included steel traps and shooting (Stewart 1806 \%; MacGregor $1828 \dagger$; Hill $1839 \dagger)$. There are varying opinions on the fox's pest status, several persons recording that it occasionally took poultry, though they differ as to whether it attacked sheep (Stewart $1806+$; MacGregor 1828†; Johnstone $1822 \dagger)$. As for their natural food, according to Bain (1890†), it was "young birds and quadrupeds", while MacGregor (1828†) more vaguely mentions that they fed "in the woods or along the shore".

\section{Black Bear}

The American Black Bear (Ursus americanus) was recorded by nineteen of the twenty-one list-makers (Table 1) and during the British period several recorders devoted a paragraph or more to it, and especially to its interactions with the human population. It would seem that in the early years bears were abundant on the island: for example, in February 1780 the ensign of a visiting regiment ([Ritter] $1780+\dagger$ ) recorded that his soldiers were shooting the bears that came near their huts at Charlottetown, while the proprietor Shuttleworth $(1793 \dagger)$ reported that where he lived (near St. Peters Bay) bears "swarmed to a degree that [he] could not have believed", and the visiting bishop Plessis $(1812+\dagger)$ said "they are seen in greater numbers than one would expect". However, just ten years later Johnstone $(1822 \dagger)$ noted that they were "decreasing in numbers greatly", with the "few of them yet in the woods" being only "seen occasionally by the inhabitants". There are similar comments on its decline by MacGregor $(1828 \dagger)$, Bagster $(1861 \dagger)$ and Anonymous $(1876 \dagger)$, with by the end of the century, Bain $(1890 \dagger)$ saying that bears were restricted to "the large wooded tracts" in the east and west of the island. Since, beginning as early as Stewart in 1806, several writers were predicting the Black Bear's impending extirpation, it comes as a surprise that the last recorded bear on Prince Edward Island was shot in 1927 (Hornby 1987).

There was an almost total antipathy to the Bear, largely due to its habit of killing livestock, a practice not discouraged by the fact that in new settlements, farm animals were let loose in the woods (e.g., Stewart $1806 \dagger$ ). Sheep are the most frequently mentioned as being taken (by fourteen recorders), followed by pigs and cattle (by eight and nine recorders respectively). Not surprisingly, these attacks seem to have been greater in the early years, Stewart (1806 $\dagger)$ recording that "the quantity of black cattle, sheep and hogs destroyed by them annually is considerable". However, later reports (Johnstone $1822 \uparrow$; MacGregor $1828 \dagger$ ) suggest that such predation was only occasional, presumably due to the decline in the number of bears. Bain (1890†) also reported that bears could do "great damage" by feeding on oats in the field.
In terms of their danger to people, the general consensus was that bears avoided humans and only attacked when either threatened or with their cubs (Stewart 1806†; MacGregor 1828†; Bagster 1861†; Sutherland 1861†; Anonymous 1876†; Bain 1890†). All the same, it was the perception of the Black Bear as a potential danger, based on perhaps a few incidents, which greatly added to the human antipathy towards them. In fact, even in the early years the list of their "evils" was considered so great that an official extermination program was instituted in the 1790s (Vass 1987). This involved the payment of a bounty of 15 shillings per bear (a large sum at the time), and remained in effect until the 1860s. Vass (1987) estimated that between 1820 and 1861 bounties were paid on over a thousand bears. Apart from the bounty, the Black Bear provided other resources to some of the island's human population: its skin was especially valuable (MacGregor $1828 \dagger$; Sutherland $1861 \dagger)$, and it was also a source of food for some, especially the Mi'kmaq (Johnstone $1822 \dagger)$, and the Acadians during their refugee years (Holland 1765 $\dagger$; Patterson $1770 \dagger$ ), and seemingly for others as well (Sutherland 1861†; Bagster 1861 $\dagger$ ).

We are told a little about the Black Bear's natural diet: several writers noted that it fed primarily on "berries", "wild fruits" and "small shrubs", as well as on insects (ant hills and grubs in old fallen trees were favourite foods), and on smelts in the spring (Stewart 1806†; MacGregor 1828†; Sutherland 1861†; [Lawson] 1877-1878†; Bain 1890†). Curiously, none of the recorders mention them feeding on the island's abundant beech mast resource, for which there is evidence from elsewhere (e.g., Vass 1987; Telfer 2004).

\section{Marten}

The American Marten (Martes americana) occurs in nineteen of the twenty-one lists (Table 1). The only comments on its abundance are Stewart's (1806 $\dagger$ ) that it was "a very shy little animal, seldom seen in the woods, though some years in great abundance", and Sutherland's $(1861 \dagger)$ inclusion of it among those mustelids that were "much more numerous" than the "comparatively scarce" otter. Bain (1890 $\dagger$ ) noted that it was "a woodland animal nesting in hollow trees and feeding on birds and small animals", and they also appear to have fed on voles during the "mouse plagues" (MacLeod 1876 $\dagger$ ). None of the recorders seemed aware of its approaching extirpation, for at some period, perhaps even in the late nineteenth century, the Marten became extinct on the island. As for its fur, several recorders commented on its value (e.g., MacGregor 1828†; Hill 1839†; Sutherland 1861†), while Holland (1765 $\dagger$ ) reported that martens were one of those animals that the refugee Acadians were compelled to use as food after the deportation of most of the French population in 1758. 


\section{Weasel}

The first record for the presence of the Short-tailed Weasel or Ermine (Mustela erminea) on the island is that of Stewart $(1806 \dagger)$ (Table 1). In fact, he treated it as two separate species, as did several later recorders. One of these he called the "weasel", which he said was "common" and "often destructive amongst poultry", while the other, the "ermine", was "uncommon" and made its nest inside fallen trees. MacGregor $(1828 \dagger)$, continuing this distinction, said that "weasels and ermines were not common", as did Bagster $(1861 \dagger)$, who, however, considered only one species to be present, which he called the ermine or "white weasel". In the same year Sutherland $(1861 \dagger)$, still listing it as two separate species, said they were "much more numerous" than the otter, and that their fur "brings a fair price", which is the only comment on its value as a furbearing animal. Apart from Stewart (1806 $\dagger$ ) above, no other author implies that it was a pest, and Bain's $(1890 \dagger)$ comment that it was "frequently seen about farmsteads where it comes in search of mice", indicates that it was then not uncommon, and at the same viewed as an assistant in mouse control.

\section{Mink}

The American Mink (Mustela vison) is first recorded in the French period (Franquet 1751†) and thereafter appears in thirteen of the British period lists (Table 1). The only comment on its abundance is Sutherland's $(1861+)$ that it was much more numerous than the "comparatively scarce" otter. Its habitat associations are encompassed in Stewart's $(1806 \dagger)$ description of it as "amphibious", while Bain (1890†) used the term "semi-aquatic", saying that it fed on fish and frogs, as well as on "small land animals". Bagster $(1861 \dagger)$ also noted fish as its main food item. In terms of its pest status, both Stewart $(1806 \dagger)$ and Bain $(1890 \dagger)$ recorded that it took poultry and eggs, while Bagster $(1861 \dagger)$ said that it also caused damage by burrowing into mill-dams. Several recorders reported its fur to be of value (Stewart 1806 \%; MacGregor $1828 \dagger$; Hill 1839†; Sutherland 1861†; Bain 1890†), though Bagster $(1861 \dagger)$ said it varied in quality.

\section{Otter}

The River Otter (Lontra canadensis) makes an appearance in seventeen of the twenty-one lists, beginning with that of La Ronde in 1721 (Table 1). Due to the high quality and monetary value of its fur (Stewart 1806†; MacGregor 1828†; Hill 1839†; Bagster $1861 \uparrow$; Sutherland $1861 \uparrow$; Bain $1890 \dagger$ ), in the British period the otter was under considerable pressure from trapping, and such trapping had also been recorded in the French period (Roma 1750†; Pichon 1760†). As early as 1806 Stewart's use of the past tense: "they have been very plenty on the island" implies they were in decline, despite his adding that "they are still caught in considerable numbers". By 1861 both Bagster and Sutherland could note that otters were "get- ting very scarce" and "comparatively scarce", respectively, Sutherland attributing this to habitat loss, or as he put it, "the increasing occupation of the country". Bain in 1890, by which time it must have been even scarcer, if not already extirpated, makes no comment at all on its abundance, instead noting that it lived in ponds and streams feeding on fish, and that when these failed, "it will attack lambs and poultry". Holland $(1765 \dagger)$ noted that it was among those animals hunted by the refugee Acadians for food.

\section{Lynx}

The Canada Lynx (Lynx lynx) was recorded by eighteen of the twenty-one list-makers (Table 1). Though it was sometimes trapped for its fur (Stewart $1806 \uparrow$; MacGregor 1828†; Bagster 1861 $\dagger$ ), and for food (Holland 1765†; Patterson 1774†; Stewart $1806 \dagger$ ), it was more generally viewed as a harmful predator of farm livestock. Johnstone $(1822 \dagger)$ said that 'wild cats' sometimes preyed on cattle and sheep in the woods, while MacGregor (1828 $\dagger$ ), Bagster $(1861 \dagger)$ and ([Lawson] 1877-1878 $\dagger$ ) noted that it specifically attacked sheep, killing several at a time without eating them. This, however, is contradicted by Stewart $(1806 \dagger)$, who said that "very few of them have been known to attack sheep or lambs". Given this reputation, it is not surprising that in the 1820 s a bounty (of five shillings) was instituted in an effort to exterminate the lynx, and from government records, Vass (1987) estimates that 357 bounties were collected between 1820 and 1861 . Given the ease with which it could be killed with dogs, or caught in snares or traps (e.g., Stewart 1806 $†$ ), combined with the loss of its habitat (Lawson $1851 \dagger$ ), it is not surprising that an animal that MacGregor (1828†) had said was "rather numerous", and Bain noted had once been "not uncommon", was by 1890 "unknown" (Bain $1890 \dagger)$. As for its natural foods, Stewart (1806†) said that it lived on "hares and partridges"; Sutherland (1861†) mentions "small mammals, mice, birds, rabbits etc."; Rowan $(1876 \dagger)$ noted its predation on hares; while Bain $(1890 \dagger)$ said it ate "small quadrupeds and birds".

\section{Seals}

The presence of seals around the shores of the island was noted by many recorders throughout the French and British periods (Table 1), but without any other information being given than that they provided a source of meat and oil to the inhabitants, as well oil and skins for export (the export of some 860 seal skins was recorded in the island's customs records between 1802 and 1807). All of the recorders write as if only a single species were present except Stewart (1806†) who distinguished between two different "kinds" of seal, one of which, he said, was "very common" in all of the rivers and harbours of the island - this presumably was the Harbour Seal (Phoca vitulina). The other, he said, was "a larger kind brought on the coast annually in the month of April by the floating ice from the 
northward; ... sometimes vast quantities come, other years little or none". This must be the Harp Seal (Phoca groenlandica), and Stewart goes on to describe the hunting of them from schooners. MacGregor (1828 $\dagger$ ) and Sutherland $(1861 \dagger)$ combine together details applicable to each of these species, without realising they were describing two separate species, Sutherland adding that by his day seals were less common than formerly.

\section{Walrus}

It is odd that French period recorders make no reference to the presence of the Atlantic Walrus (Odobenus rosmarus) along the shores of the island, though La Ronde (1721†) noted the presence of the 'vache marine', as he called it, in the Magdalen Islands, to which he said they were sending a ship from the island to participate in the summer hunt. The first record of the walrus directly on the island itself is thus that of the British surveyor Samuel Holland (1765†) (Table 1), who, however, stated that they "seldom or never come on shore but are now and then killed in the spring by the inhabitants in their canoes, when they happen to float too near the shore on pieces of ice". This, however, conflicts with some of the later British records, especially that of Stewart $(1806 \dagger)$, who claimed that in the 1770s (he himself having arrived on the island in 1775) "sea cows" had been "found in great numbers on the north coast" (he especially mentions the area near North Cape), and he added that between 1770 and 1775 they were caught in considerable numbers there, the method being to drive the herds inland and then slaughter them using long spears. However, at the time that he was writing in 1806 he said that they "are now become scarce and seldom seen ashore". All of the later historical records for the presence of the walrus are thus retrospective (e.g., MacGregor $1828+$; Hill 1839†; Sutherland $1861 \dagger$ ), and all state that it was no longer observed around the island. The animal was killed especially for its oil, but there is also mention of the value of its hide for making ropes, harness and shoes (e.g., Curtis 1775††; Stewart 1806†; MacGregor 1828†; Hill 1839†; [Lawson] 1877-1878†), as well as of its tusks for ivory (e.g., Stewart 1806†; MacGregor $1828 \dagger$ ).

\section{Caribou}

The first record of the presence of the Woodland Caribou (Rangifer tarandus) on the island is that of Nicholas Denys $(1672 \dagger \dagger)$ : he said that there were only a few on account of the Mi'kmaq being too fond of them for food to allow them to increase. Somewhat in conflict with this statement is that of La Ronde $(1721 \dagger)$, who said that the Mi'kmaq did not find the Caribou easy to kill. The last French period record of their presence is that of Roma (1750†), who had left the island in 1746 . The only record of their possible survival into the British period is that of Holland
$(1765 \dagger)$ who noted that there were "some, but very few Carriboux". If the species was still present in 1765 , then it would seem to have become extinct shortly after, for ten years later, in 1775, Thomas Curtis recorded that none of the inhabitants whom he had met (and one of these had been resident since 1768) knew of any "deer" on the island (Curtis 1775††). I also say "if" for Holland's record because, as has often been demonstrated elsewhere, there is a tendency for people to believe that an extirpated animal is still present long after its disappearance, so that Holland, perhaps having been told by the Acadians of its past presence in small numbers, recorded it as still present. It is also significant that he did not include them as one of the animals that the refugee Acadians hunted for food, which they surely would have done, had it been present. Thereafter in the nineteenth century, the past presence of the Caribou was witnessed by the occasional finding of a "time-worn" antler in the woods (Lawson 1851†; Bagster 1861†; Rowan 1876 $†$ ), though such antlers were also sometimes erroneously cited as evidence for the past occurrence of the Moose on the island (see below).

\section{Squirrels and Chipmunk}

That squirrels occur in only thirteen of the twentyone lists (Table 1) is an indication not of their scarcity, but that, being of little value as either food or for their fur, they tended to be overlooked, except by those who set out to list all of the island's mammals. In fact during the French period the only recorder to note the presence of any of the squirrel species was La Ronde $(1721 \dagger)$, who recorded the elusive flying squirrel, presumably because of its unusual mode of movement. In the early decades of British settlement, although several recorders noted the presence of different "kinds" of squirrel, they did not name them. Thus it was not until 1806 that the three species currently occurring are specifically recorded: the American Red Squirrel (Tamiasciuris hudsonicus), the Eastern Chipmunk (Tamias striatus), and the Northern flying squirrel (Glaucomys sabrinus) (Stewart 1806 $\dagger$ ), and thereafter, all three are listed by another five recorders (Table 1).

The red squirrel and the chipmunk were considered very plentiful (Stewart 1806†; Johnstone 1822†; Sutherland $1861 \dagger$ ), but due to its nocturnal and elusive habits there was some uncertainty as to the abundance of the flying squirrel: Stewart $(1806 \dagger)$ considered it not as common as the other two species, though Bain $(1890 \dagger)$ said it was "not rare". Stewart $(1806 \dagger)$ said that all three species, and particularly the chipmunk, increased "vastly" the year after a crop of beech mast, while Bain (1890†) said that the red squirrel was "plentiful in every wood where beech nuts were found". Bain (1890†) said that the chipmunk dug its burrow "under the roots of the great trees in a spruce wood", while the flying squirrel nested in hollow trees. 


\section{Muskrat}

The Muskrat (Ondatra zibethicus) was listed by fifteen of the twenty-one list makers (Table 1), most of whom make no further comment about it. Though Bagster (1861†) said it was "by no means plentiful", Rowan (1876 $\dagger$ ) considered it to be "very plentiful", and Stewart (1806 $\dagger$ ), Sutherland $(1861 \dagger)$, and Bain $(1890 \dagger)$ said it was frequently seen about streams and ponds. There were opposing opinions about the value of its pelt: Bagster $(1861 \dagger)$ said the fur was "useful and saleable", while Sutherland (1861 $\dagger$ ) said it was "thin and poor and little esteemed". Holland (1765†) included Muskrats as one of the animals that the refugee Acadians used for food, while Bain (1890 $\dagger$ ) noted that Muskrats, due to their habit of burrowing into the banks, were "troublesome about mill dams". As for its natural foods, Sutherland (1861 $\dagger$ ) and Bain $(1890 \dagger)$ noted that it ate roots, shellfish and seeds.

\section{"Plague Mouse"}

During the French period, as well as in the first eighty years of British settlement, virtually the only species of mouse or vole that entered the records was the one responsible in occasional years for the destruction of the settlers' crops. This "plague mouse" damaged the crops several times during the French regime (e.g., Roma 1750†; Franquet 1751†; La Roque $1752 \dagger \dagger$ ), while during the British period there were at least eight further outbreaks between 1770 and 1815 (Sobey 2006). However, by 1828 MacGregor noted that within the previous twenty years little injury had been done to the crops by "these mischievous animals".

Identifying the species responsible for the outbreaks has not been easy. Roma's (1750†) detailed description of the habits of the vole that caused the fléau [plague] of 1738, appears to better fit the Southern Red-backed Vole (Clethrionomys gapperi), rather than the Meadow Vole (Microtus pennsylvanicus), which has been more generally viewed as the culprit (e.g., MacQuarrie 1987): Roma's mulot, as he called it, was a woodland species (this, confirmed by all of the other French and British recorders, fits only the Southern Red-backed Vole); it made substantial underground food caches for the winter; and it was able to climb (although Roma said not as well as the souris (probably the Deer Mouse, Peromyscus maniculatus). These last two properties are characteristic of the Southern Red-backed Vole as described by Hamilton and Whitaker (1979) and Godin (1977), and appear not to apply to the Meadow Vole. However, I note that Banfield (1974) states that the Southern Red-backed Vole does not store up food for winter, whereas he says the Meadow Vole does. Unfortunately, the subsequent British period recorders do not supply any additional information that would enable us to settle the matter: what records there are, indicate the animal was a largish "mouse" with a short tail (e.g., Patterson 1770†; Shuttleworth $1793 \dagger$ ). Even so, the further history of the outbreaks - the fact that they occurred only during the pioneer phase when new clearings were being opened up in the forest, and ceased as the forests were cleared - points also to the Southern Red-backed Vole.

Two alternative theories were proposed for the cause of the outbreaks by contemporary observers. Roma $(1750 \dagger)$ and Patterson (1770†) considered that winters with heavy snow gave the voles protection from their predators, at the same time allowing them to feed from their stores under the snow; whereas Franquet $(1751 \dagger)$, La Roque (1752††), Stewart (1806†) and Plessis $(1812 \dagger \dagger)$ considered that the high production of beech mast in certain years was the cause. It is impossible retrospectively to determine which if either of these explanations is correct.

\section{Other mice and voles}

The first mention of a mouse other than the "plague mouse" is, Roma's (1750†) reference above to the souris [mouse] that he said was a better climber than the plague vole - this can only be the Deer Mouse. The next mention is over a century later: Sutherland $(1861 \dagger)$ refers to two species of "field mice": the "burrowing field mouse", which appears from his description to be the Meadow Vole, and the "leaping field mouse", which, given its "long tail and strong hind legs", is likely to be the Meadow Jumping Mouse (Zapus hudsonius). Sutherland did not realize that there was another species of jumping mouse on the island, the Woodland Jumping Mouse (Napaeozapus insignis), first recorded by Cameron (1958).

The only other recorder to distinguish between the native species of mice and voles was Bain $(1890 \dagger)$ who listed three native species: his "short-tailed Meadow Mouse" can only be the Meadow Vole since his brief description fits this species: "it lives on grain and grasses, and builds a nest of dry grass and makes long galleries under the snow in winter when it causes much destruction by barking young orchard trees". His two other species were "much less common": his "WhiteFooted Mouse" can only be the Deer Mouse, while his "Hamster Mouse" must be the Southern Red-backed Vole. He thus did not record either species of jumping mouse.

\section{Snowshoe Hare}

The Snowshoe Hare (Lepus americanus) is listed by all but two of the list-makers (Table 1), with many of the recorders noting that hares were abundant on the island. The only recorders to give any information on its habitat are Rowan (1876†), who said "their favourite resort is the second growth of young forest", and Bain (1890†), who noted they liked "dry ground in summer but frequent the swamps in winter". This was presumably related to the food they fed on in winter, which Bain $(1890 \dagger)$ said was "young shoots of trees" - these were more specifically identified by Rowan (1876 $\dagger$ ) as "the tender twigs of maple, moosewood, birch, willow, alder etc.". Both recorders said 
that in summer they fed on "grass". Rowan said that on the island their natural enemies were the Lynx, Marten, Weasel and Fox, as well as birds of prey, and man. Almost all of the recorders refer to the Snowshoe Hare in the context of a game animal, and in the early years of settlement it seems to have been an important supplementary food source for the human population (e.g., Curtis 1775††; Chappell 1775-1818††). Hares continued to be eaten throughout the nineteenth century and were considered a delicacy by many. However, Johnstone (1822 $\dagger$ ) and Sutherland $(1861 \dagger)$ considered their fur to be of little value.

\section{Absences in the records Moles}

Although Johnstone $(1822 \dagger)$ stated categorically that "there is not a mole on the island", two later writers of school textbooks for the island (Sutherland $1861 \uparrow$; Bain $1890 \dagger)$, included it in their lists of the island's mammals, both using similar phrasing: "it burrows in the ground and lives on worms". Despite their assertions, there is no evidence that a species of mole has ever occurred on Prince Edward Island, and neither Cameron (1958) nor ACCDC (2008*) have included it in their lists of the native mammals.

\section{Fisher}

The Fisher (Martes pennanti), which currently occurs in Nova Scotia and New Brunswick, is entirely absent from the historical records for the island. Thus the inclusion of Prince Edward Island in the animal's historical range by Cameron (1958), Peterson (1966), Banfield (1974) and ACCDC (2008*) is not supported by the early records.

\section{Moose}

There is no historical evidence that the Moose (Alces alces) ever occurred on Prince Edward Island, at least during the settlement period, and in fact there is strong evidence to the contrary: during the French period Denys (1672††) and La Ronde $(1721 \dagger)$ had made a point of recording that the Moose was absent from the island, as did Sutherland (1861 $\dagger$ ) during the nineteenth century. The five British period records of its occurrence are late and retrospective (Table 1), and are all based on the anecdotal finding of "moose horns" in the woods - it was this evidence that led Cameron (1958) and Banfield (1974) to list the Moose as once occurring on the island. These "horns", however, are far more likely to have belonged to the Caribou, for which there is irrefutable evidence of its past occurrence.

\section{Beaver}

The only historical record for the occurrence of the American Beaver (Castor canadensis) on Prince Edward Island (that is, prior to its deliberate introduction in the twentieth century) is that of Bain $(1890 \dagger)$ who said that it was "once common here and the remains of its dams are still to be seen in many parts of the country". This is a curious statement since fourteen years earlier Rowan (1876 $\dagger$ ) had said that he had not seen or heard of any "beaver works" on the island, and so he was "inclined to think" they had "never lived on the island", as "their traces endure long after they have become extinct". So also had Sutherland $(1861 \dagger)$ included it in a list of the mammals found on the mainland that did not occur on the island. The validity of Rowan's and Sutherland's observations is strongly supported by the fact that its absence from the island had been noted at the beginning of French settlement by La Ronde $(1721 \dagger)$, as well as by the fact that none of the other list-makers had included the beaver in their lists of the island's mammals, including Stewart (1806 $\dagger)$, Johnstone $(1822 \dagger)$ and MacGregor $(1828 \dagger)$ who had made fairly comprehensive lists. Given the commercial importance of its fur and its relatively large size, it was a mammal that, had it been present, would not have been overlooked. Apart from Bain's comment, the only other mentions of the beaver that I have come across in the historical records are its inclusion in a list of the retail prices of pelts, printed in a pamphlet for immigrants to the island (Anonymous $1808+\dagger)$, and the presence of beaver pelts among a consignment of animal skins shipped to Halifax in 1802 (Sobey 2006). Since pelts were easily transportable from the mainland, where the species did occur, neither record indicates its presence on the island. It should be noted that the beaver's absence from the island from 1720 onward does not exclude the possibility that it had been trapped-out prior to the eighteenth century. The evidence in support of such a view, however, is limited to the finding of a beaver incisor tooth in an archaeological dig at a prehistoric aboriginal site (probably Mi'kmaq) near East Point that was occupied from about 800 to $1000 \mathrm{AD}$ (Keenlyside 1983) (though such a small item could have been easily carried from the mainland), and the unreferenced statement of Cameron (1958) that beaver tooth-marks had been found on sticks from island peat-bogs.

\section{Other absences}

Sutherland $(1861 \dagger)$ noted the absence of the Raccoon (Procyon lotor) from the island, as well as the American Porcupine (Erethizon dorsatum) (as had La Ronde IN 1721 $\dagger$ ), both of which he noted as occurring in Nova Scotia and New Brunswick; while Rowan $(1876 \dagger)$ noted the absence of the "Virginian deer" (i.e., the White-tailed Deer, Odocoileus virginianus). The validity of these statements is supported by the fact that none of these animals was noted as present by any other of the historical recorders.

\section{Discussion}

\section{The island's native mammalian fauna}

Thirteen of the island's native terrestrial mammals were recorded by French period observers (Table 1), 
with British period recorders taking the total to twenty. On the basis of the current ACCDC (2008*) mammal list for the island, we may surmise that the number of terrestrial species at the time of settlement might have been 28. This includes my deletion of the beaver and Fisher from the ACCDC list, and ignores the post-settlement arrivals of the Brown Rat (Rattus norvegicus), House Mouse (Mus domesticus), Striped Skunk (Mephitis mephitis), Racoon and Coyote (Canis latrans), the latter three in the twentieth century. The eight omissions from the historical record are all small mammals: the island's five species of shrew (assuming those currently in the ACCDC list were also present in the eighteenth century) were treated by the early recorders as one species, as were the four species of bat; while one of the five species of native mice and voles went unrecorded (the Woodland Jumping Mouse Napaeozapus insignis, first recorded by Cameron 1958). As for the marine fauna, three species are distinguished in the historical records: the Walrus, and seemingly, the Harbour Seal and Harp Seal. Thus the two other seal species listed by ACCDC (2008*) as currently occurring in the Gulf of St. Lawrence (the Grey Seal, Halichoerus grypus and Hooded Seal, Cystophora cristata) are not discernable in the historical records for the island.

Despite the absence of three key boreal elements from the records (the Moose, porcupine and beaver), the terrestrial fauna recorded at the beginning of European settlement is a boreal fauna, signalled in the records by the presence of the Snowshoe Hare, Red Squirrel, Northern Flying Squirrel, Southern Redbacked Vole, American Marten, Short-tailed Weasel, Canada Lynx, and Woodland Caribou. All of the other mammals recorded (e.g., the American Black Bear, Grey Wolf, Red Fox, American Otter, Mink and Muskrat) are also quite at home in the boreal forest zone, though occurring widely in more southerly areas as well (e.g., Banfield 1974; Hall 1981). Concomitantly, there is a total absence of mammals characteristic of the more southern deciduous forest zone (e.g., the Striped Skunk, Racoon, Eastern Grey Squirrel, Sciurus carolinensis, and White-tailed Deer); and if Denys $(1672 \dagger \dagger)$ is to be relied upon, none of these were present in the rest of Acadia (including eastern Maine) in the seventeenth century - though in the last two centuries such southern species have reached the adjacent mainland and some have even been introduced onto the island (i.e., Striped Skunk and Racoon).

The presence of the Woodland Caribou, along with its predator, the Grey Wolf, is one of the more interesting pieces of information to emerge from the records of the period, and is a corrective to Lohr and Ballard's (1996) statement that wolves never occurred on Prince Edward Island. As I have noted, it seems that neither species was abundant, and La Ronde $(1721 \dagger)$ said that the reason the Mi'kmaq did not spend the winter on the island was that they found the Caribou difficult to kill (he actually called them cerfs or "deer"), the implication being that there was little else for them to eat in winter - which would indeed have been so, given the absence of the beaver and the Moose, two of their traditional winter food animals (e.g., Denys $1672 \dagger \dagger$ ). We thus have here a clear instance of the natural fauna (both presences and absences) having important effects on the aboriginal population.

\section{The importance of the beech forests}

The historical evidence indicates that American Beech was a very important tree in the upland hardwood forests of the island, with large areas of the land surface being covered by beech forest (Sobey 2006). Beech produces a nut (traditionally called mast), which provides an important food for many different animals (e.g., Tubbs and Houston 1990). In the historical records for the island we are told, as we have seen, that the Red and Flying squirrels, the chipmunk and the "plague mouse" fed on the mast, as also, we may presume, did all of the other woodland mice and voles. Evidence from elsewhere (e.g., Vass 1987; Telfer 2004) indicates that the American Black Bear was also likely to have done so.

The North American Beech has long been known to be irregular in its seed production, with "mast years" occurring every two to eight years (Tubbs and Houston 1990). That the beech forests on the island also exhibited such mast years is recorded by Franquet $(1751 \dagger)$, La Roque $(1752 \dagger \dagger)$, Stewart $(1806 \dagger)$, Plessis $(1812 \dagger \dagger)$ and Bain (1868-1884††). As we have seen, such mast years were considered by some to be the cause of the vole irruptions, while Stewart $(1806 \dagger)$ said that the three squirrel species (and of these, especially the chipmunk) also showed a "great increase" in numbers "after an abundant crop of beech mast". And though they did not enter the written record, we may presume that all of the other feeders on beech mast would also have been affected. As well, the distribution of beech forests on the island might have affected the spatial distribution of the mast-feeders, and this may not have been only in mast years. However, the only evidence that we have for this is Bain's $(1890 \dagger)$ comment that the red squirrel was "so plentiful in every wood where beech nuts are found".

Given this recorded increase in the mast-eaters, we might expect that the island's predator populations might have concentrated on them when they were abundant - Roma ( $1750 \dagger)$ had certainly noted that the fox and the marten fed on the voles during a plague year. We have a hint that this abundance of prey may have also led to a increase in the numbers of the predator species, in Franquet's $(1751 \dagger)$ statement that foxes, martens, mink and lynx were more abundant in some years than in others, as well as Stewart's $(1806 \dagger)$ that the marten was in "great abundance" in some years. However, confounding factors here are the so-called "long" or "nine to ten year cycle" in the numbers of the Snowshoe Hare and its predators (especially the 
lynx) that has long been recorded throughout its North American range and the "short" cycle (of two to three years) that commonly occurs among rodents and their predators in northern environments (e.g., Finerty 1980).

We can only speculate on the effect that the great decline in the area of beech forest has had on the ability of the forests to sustain the food-webs that they did before European settlement. Prior to forest clearance, beech was a predominant tree, Stewart (1806 $\dagger$ ), for example, saying that "one-half of the island is covered with it, in some districts it forms nine-tenths of the forest". By 1991, however, beech contributed only $4.1 \%$ of the woody biomass in the remaining upland hardwood forest (Sobey and Glen 2002), and far less when all of the forest-types are considered. Thus those mammals still occurring on the island that were once substantial mast-eaters (the chipmunk, squirrels, voles and mice) have had to turn to other types of food.

\section{The utilization of the mammalian fauna for food and} fur

All of the French period mentions of the Caribou refer to it in the context of game, either for the aboriginal Mi'kmaq (Denys $1672 \dagger+$; La Ronde $1721 \dagger$ ) or the new French settlers (Gotteville de Belile 1720†+; Roma $1750 \dagger)$. Then, after the Caribou's extirpation in the mid-eighteenth century, the animal most mentioned as a source of food is the Snowshoe Hare. As well, other animals that most people nowadays would not consider edible are also recorded as being eaten by the European population, notably the bear and the lynx, while Holland $(1765 \dagger)$ reported that the refugee Acadians were eating even martens, otters and Muskrats. The island's seals also served as food for the Acadian population in the early years (La Ronde $1721 \dagger$; Roma 1750†; Patterson $1770 \dagger$ ), as did oil from the walrus (Stewart 1806†). However, once settlement was established, the native fauna seems to have become unimportant as a food source, though the hare continued to be mentioned as a game animal throughout the nineteenth century.

Would the hunting of any of these animals for food have had any effect on their numbers? It is probably not a coincidence that the Caribou disappeared from the island within a few decades of the establishment of the first permanent settlement in 1720: the small numbers reported to occur (e.g., Denys 1672 ††; Holland $1765 \dagger$ ) would have been vulnerable to even low levels of hunting. Also, the hunting of the walrus for its oil may have contributed to its disappearance from island waters. By contrast, the Snowshoe Hare continues to thrive on the island, and any hunting, even in the unregulated early days, seems to have had little effect.

As for those animals that served as food only under extreme conditions, it is clear that hunting was another pressure that contributed to their extirpation, namely, their being hunted for their furs. However, though many recorders, as we have seen, stress the value of the furs of the otter, marten, mink, Red Fox, and black bear, and to a less extent the lynx and the Short-tailed Weasel, concrete data on any fur trade that developed on the island is sparse in the historical record. For the French period, the only specific references are Roma's (1750†) comment that "la chasse aux martres [i.e., marten-hunting] should be reserved to the Mi'kmaq to enable them to "procure their needs", and the entry in the 1757 journal of an officer aboard a French warship at Louisbourg that "the Indians of Île Saint-Jean usually come to Louisbourg in August and September to sell their animal pelts which brings them a very good profit" (Sobey 2006).

In the British period, the only recorder to give the fur trade more than a passing mention is Samuel Hill $(1839 \dagger)$, who wrote that "there was once a considerable export of furs from the island". The island's customs records contain evidence of two such early fur shipments: the Betsy, bound for Halifax in June 1802, had amongst its cargo " 4 Trunks of furs, containing Rabbit, Fox, Martin, \& Beaver skins, a few seal skins \& 30 Dozen loose rabbit skins"; while in May 1819 the Nelly, also bound for Halifax, had 1200 "rabbit" skins, 162 martin, 14 otter, 1 lynx, and 1 bear. (The presence of beaver skins in the 1802 shipment indicates that at least some of the furs had come from the mainland.) Also, the inventory of the estate of one John Rennie in 1791 recorded that at his death he was in possession of "six dozen dressed marten skins" (Nicholson 2004).

When Hill goes on to comment on the fur trade of the 1830s he highlights the role of the Mi'kmaq: "foxes are chiefly shot or trapped by the Indians, and their skins exported to England by the resident merchants", and other writers also refer to the skills of the Mi'kmaq in the trapping of the native fauna (Johnstone $1822+$; MacGregor $1828 \dagger$ ). And there is also an 1830 s record of the export of furs in the customs records: the Catherine Jane bound for Liverpool in May 1834 carried 493 fox pelts (of which 19 were cross and 4 silver), 440 marten, 60 "rabbit", 40 lynx, 31 otter, 29 mink, 2 Raccoon, and 1 Muskrat. As was so for the beaver above, the presence of the two Raccoon pelts indicates that some of the skins must have come from the mainland, since the Raccoon is otherwise absent from the historical records for the island.

\section{Extirpations among the fauna}

Four of the fur-bearers were eliminated from the island: the marten, otter, lynx and black bear, as were also the caribou and the wolf - as well as the walrus from the waters around the island. We may question whether all of these extirpations were inevitable. Granted that the large-scale destruction of forest to make way for farmland would have resulted in a considerable loss of habitat and a resulting decline in the total numbers of all of the terrestrial mammals; even 
so, with the exception of the caribou and the wolf, which are both likely to have required a greater area of forested habitat than what remained, the other four land mammals should have been able to survive in the remaining areas of forest and other habitat. In the British Isles the Pine Marten (Martes martes) and European Otters (Lutra lutra) have been able to survive in landscapes greatly altered by human activity, and in association with as high or even higher human population densities than on Prince Edward Island (e.g., Corbett and Southern 1977; Jefferies 1989). It thus seems that had there not been the uncontrolled trapping of the marten - an animal notoriously easy to trap (e.g., Banfield 1974; Hamilton and Whitaker 1979) - it very likely could have survived. As for the Otter, though habitat loss may have played a role, the rivers and bays that were its habitat being directly adjacent to the areas first selected for settlement, unregulated trapping appears also to have been the main reason for its extirpation. In fact, it was not until 1879 that the island's House of Assembly passed its first act "for the protection of Game and Fur-bearing Animals", which, among other measures, restricted the season for taking Muskrat, marten, and otter to between 1 November and 1 May (Glen1995).

As for the lynx and the black bear, had there not been active hostility towards them, including the institution of bounties, it is possible that they could also have survived. According to Anonymous (2003*), "as long as they are not disturbed", lynx are "remarkably tolerant of human settlement" (see also Poole (2003)), while the last bear on the island was shot as late as the $1920 \mathrm{~s}$ - some forty years after the peak of human population density. As for the Walrus, though the island's first British governor was aware of the need for controls on the "sea cow fishery" and even had his council pass an ordinance in 1770 to regulate it, he was aware that the hunt, being largely carried out by "vessels from New England", was beyond the control of his infant government (Patterson 1774 $\dagger$ ).

We may thus conclude that though the activities of the settler population led to the seven extirpations, an important factor contributing to four of them was the attitude of the settlers: a positive hostility to the lynx and the bear (understandable in the light of their predation on livestock), and an indifference to the survival of the otter and the marten so that the necessary protections were not instituted until it was too late.

\section{Acknowledgments}

I thank Professor Gerry McKenna, then Dean of Science at the University of Ulster, for enabling me to take six months sabbatical in 1996 so that I could initiate the study, and Harry Baglole of the Institute of Island Studies at the University of Prince Edward Island for supporting a research associateship at the university. I also thank the staff responsible for the
P.E.I. Collection at the Library of the University of P.E.I. and those at the P.E.I. Public Archives and Record Office for assisting me with locating and copying documents, as well as the P.E.I. Department of Environment, Energy and Forestry, and in particular William Glen and Kate MacQuarrie, for supporting the research. I also thank William Glen for directing me to some of the fur data in the customs records.

Documents Cited (marked $*$ in text)

ACCDC. 2008. Species Rarity Ranks: Prince Edward Island Vertebrates. Atlantic Canada Conservation Data Centre, Sackville, New Brunswick. At website: www.accdc.com

Anonymous. 2003. The Canada Lynx. Hinterland Who's Who. Canadian Wildlife Service, Environment Canada. At website: www.hww.ca.

\section{Literature Cited}

Banfield, A. W. F. 1974. The Mammals of Canada. University of Toronto Press, Toronto, Ontario.

Cameron, A. W. 1958. Mammals of the Islands in the Gulf of St. Lawrence. National Museum of Canada Bulletin (154).

Clark, A. H. 1959. Three Centuries and the Island. University of Toronto Press, Toronto.

Corbet G. B., and H. N. Southern. 1977. The Handbook of British Mammals. Blackwell Scientific Publications, Oxford.

Finerty, J. P. 1980. The Population Ecology of Cycles in Small Mammals: Mathematical Theory and Biological Fact. Yale University Press, New Haven.

Glen, W. M. 1995. Prince Edward Island Wildlife Legislation: 1780-1951. Department of Agriculture, Fisheries and Forests, Charlottetown.

Glen, W. M. 1997. Prince Edward Island 1935/1936 forest cover type mapping. Department of Agriculture and Forestry, Charlottetown.

Godin, A. J. 1977. Wild Mammals of New England. John Hopkins University Press, Baltimore.

Hall, R. E. 1981. The Mammals of North America (Second edition). J. Wiley and Sons, New York.

Hamilton, W. J., and J. O. Whitaker. 1979. Mammals of the Eastern United States (Second edition). Cornell University Press, Ithaca.

Hornby, J. 1987. Bear facts: the history and folklore of Island bears. Part One. The Island Magazine 22: 3-9.

Jefferies, D. J. 1989. The changing otter population in Britain 1700-1989. Biological Journal of the Linnean Society 38: 61-69.

Keenlyside, D. L. 1983. In search of the Island's first people. The Island Magazine 13: 3-7.

Lohr, C., and W. B. Ballard 1996. Historical occurrence of Wolves, Canis lupus, in the Martime Provinces. Canadian Field-Naturalist 110: 607-10.

MacQuarrie, I. 1987. Plagues of mice. The Island Magazine 21: $15-18$

Nicholson, L. J. 2004. Early Prince Edward Island Probate Records 1786-1850. Transcontinetal Publications, Charlottetown, P.E.I.

Peterson, R. L. 1966. The Mammals of Eastern Canada. Oxford University Press, Toronto.

Poole, K. G. 2003. A review of the Canada Lynx, Lynx canadensis, in Canada. Canadian Field-Naturalist 117: 360-76 
Scott, F. W., and A. J. Hebda. 2004. Annotated list of the mammals of Nova Scotia. Proceedings of the Nova Scotia Institute of Science 42: 189-208.

Sobey, D. 2002. Early Descriptions of the Forests of Prince Edward Island: I. The French Period (1534-1758). P.E.I. Department of Forestry and Agriculture, Charlottetown.

Sobey, D. 2006. Early Descriptions of the Forests of Prince Edward Island: II. The British and Post-Confederation Periods (1758 - c.1900). P.E.I. Department of Environment, Energy and Forestry, Charlottetown.

Sobey D. G., and W. M. Glen. 2002. The forests of Prince Edward Island: a classification and ordination using multivariate methods. Canadian Field-Naturalist 116: 585-602.

Sobey D. G., and W. M. Glen. 2004. A mapping of the present and past forests of Prince Edward Island. Canadian Field-Naturalist 118: 504-520.

Telfer, E. S. 2004. Continuing environmental change - an example from Nova Scotia. Canadian Field-Naturalist 118: 39-44.

Tubbs, C. H., and D. R. Houston. 1990. Fagus grandifolia Ehrh. American Beech. Pages 325-332 in Silvics of North America. Volume 2: Hardwoods. Edited by R. M. Burns and B. H. Honkala, Forest Service, U.S. Department of Agriculture, Washington, D C.

Vass, S. 1987. The black bear on Prince Edward Island: a natural history. The Island Magazine 22: 8-9.

\section{The List-makers Cited in Table 1 (listed in}

chronological order and marked $\dagger$ in text)

La Ronde, Louis Denys de. 1721. Letter to the Minister of the Marine, 6 November 1721. PAC, AC, $\mathrm{C}^{11} \mathrm{~B}$, Volume 5, fols. 436-37v.

Roma, Jean-Pierre. 1750. Letter to the Minister of the Marine, 11 March to 14 May. PAC, $\mathrm{AC}, \mathrm{C}^{11} \mathrm{~B}$, Volume 29, fol. 376.

Franquet, Louis. 1751. Voyage du Sieur Franquet ... [à] l'ile Saint-Jean. Report to the Government of France in his capacity as Inspector-General of Fortifications. PAC, AC, $\mathrm{C}^{11} \mathrm{~V}$, Volume 9, fol. 376 ff. [Published 1924 as: Le voyage de Franquet aux Îles Royale et Saint-Jean, in Rapport de L'Archiviste de la Province de Québec pour 192324, pages 111-140.]

Pichon, Thomas. 1760. Lettres et Mémoires pour server à l'Histoire Naturelle, Civile et Politique du Cap Breton. P. Gosse, La Haye; J. Nourse, London. Published also in English in 1760 as: Genuine Letters and Memoirs, Relating to the Natural, Civil and Commercial History of the Islands of Cape Breton, and Saint-John .... J. Nourse, London. [French version reprinted 1966 by S. R. Publishers Ltd., Johnson Reprint Corporation].

Holland, Samuel. 1765. Letter to Richard Cumberland Esq., Agent to the Provinces of Quebec and Nova Scotia, containing a 'Report of Survey', 8 October 1765. [Handwritten transcript in PEI PARO: Accession 2324/8A.]

Patterson, Walter. 1770. Letter to the Earl of Hillsborough, 24 October 1770. PEI PARO: CO-226/1, fols. 11-12v.

Patterson, Walter. 1774. Letter to the Secretary of State, 1 May 1774. PEI PARO: CO-227/2, fols. 42-50v.

Shuttleworth, Robert. 1793. Letter to Sir Joseph Banks, 8 October 1793. [Printed in: D. A. Webber 1992. Robert Shuttleworth, the opulent gentleman from Morell. The Island Magazine 31: 3-10.]

[Cambridge, John]. c.1796. A Description of the Island of St. John, in the Gulf of St. Laurence, North America .... . R. Ashby and Co.; W. Winchester and Son; London.
[Reprinted 1805 and 1818 with additions.]

Walsh, Edward. 1803. Travel Journal. [An extract was published 1984 (with an introduction by H. T. Holman) as: An Account of Prince Edward's Island, The Island Magazine 15: 9-13.

Stewart, John. 1806. An Account of Prince Edward Island, in the Gulph of St. Lawrence, North America. Winchester and Sons, London. [Reprinted 1967, S. R. Publishers.]

Johnstone, Walter. 1822. A Series of Letters Descriptive of Prince Edward Island in the Gulph of St. Lawrence. J. Swan, Dumfries. [Re-published 1955 in Journeys to the Island of St. John or Prince Edward Island. Edited by D. C. Harvey. MacMillan, Toronto. pages 87-161.]

MacGregor, John. 1828. Historical and Descriptive Sketches of the Maritime Colonies of British North America. Longman, Rees, Orme, Brown and Green, London. [Reprinted 1968 by S. R. Publishers, Johnson Reprint Corporation.]

Hill, Samuel Smith. 1839. A Short Account of Prince Edward Island. Madden and Co., London.

Lawson, John. 1851. Letters on Prince Edward Island. Hazard, Charlottetown, P.E.I.

Bagster, C. Birch. 1861. The Progress and Prospects of Prince Edward Island. John Ings, Charlottetown, P.E.I.

Sutherland, George. 1861. Manual of the Geography and Natural and Civil History of Prince Edward Island. John Ross, Charlottetown, P.E.I.

Rowan, John J. 1876. The Emigrant and Sportsman in Canada. Edward Stanford, London. [Reprinted 1972 as a facsimile edition by Coles Publishing, Toronto].

Anonymous 1876. Questionnaire circulated to the oldest inhabitants. PEI PARO: Smith-Alley collection: Accession 2702, Series 20, 296-317.

[Lawson, Stephen G.] 1877-1878. [A series of articles on pioneer days.] The Presbyterian and Evangelical Protestant Union, Charlottetown. February 1877 to March 1878. [The relevant extracts are reprinted in Sobey (2006).]

Bain, Francis. 1890. The Natural History of Prince Edward Island. G. H. Hazard, Charlottetown, P.E.I.

Additional Historical Documents Cited (listed in chronological order and marked $\uparrow \dagger$ in text)

Denys, Nicolas. 1672. Description geographique et historique des costes de l'Amerique Septentrionale, avec l'Histoire naturelle du Païs. [Re-published 1908 by the Champlain Society (with an English translation), edited by W. F. Ganong - this was reprinted in 1968 as a facsimile edition by Greenwood Press, New York.]

Gotteville de Belile, Robert-David de. 1720. Letter to the Council of the Marine. PAC, AC, $\mathrm{C}^{11} \mathrm{~A}$, Volume 43, fols. 134-36.

La Roque, Joseph de. 1752. Voyage d'inspection du Sieur de la Roque, Recensement 1752. [Published 1906 in Rapport concernant les Archives canadiennes pour l'année 1905, Volume II, pages 1-168. Imprimerie du Roi, Ottawa. English translation in Report concerning Canadian Archives for the year 1905, Volume II, Appendix A, Part 1, pages 1-172].

Curtis, Thomas. 1775. A Narative of the Voyage of Thos. Curtis to the Island of St. John's in the Gulf of St. Lawrence in North America, in the year 1775. Published 1955 in Journeys to the Island of St. John or Prince Edward Island. Edited by D. C. Harvey. MacMillan, Toronto, pages 9-69] 
Chappell, Benjamin. 1775-1818. Daybooks. P.E.I. PARO: 2227. [Published 2003 by the P.E.I. Genealogical Society, Charlottetown, as: The Daybooks of Benjamin Chappell (Edited by L. Chappell)].

[Ritter, Ensign]. 1780. The regimental log of the von Knyphausen Fusilier Regiment (8 September 1779 - 30 June 1780). [An English translation by L. Zimmermann of the original German was printed 1987 in Abegweit Review 5: 20-28].

Anonymous. 1808. A True Guide to Prince Edward Island, formerly Saint John's in the Gulph of St. Lawrence, North America. G. F. Harris, Liverpool.
Plessis, Joseph-Octave. 1812. Le journal des visites pastorelles de Mgr. J.-O. Plessis (Evêque de Québec) en Acadie 1811, 1812, 1815. [Published 1980 in Les cahiers de la société historique acadienne 11: 1, 2, 3.]

Bain, Francis. 1868-1884. Notes in Natural History, 18681877 and $1877-1884$. Unpublished notebooks, P.E.I. PARO 2353/95 and 92.

MacLeod, D. 1876. Memoir of Norman MacLeod, D.D. by his Brother. Belford Brothers, Toronto.

Received 13 July 2007

Accepted 25 July 2008 